\title{
Design and Evaluation of a Flexible Pickup Coil for a Magnetostrictive Torque Sensor with a Reduced Offset and Closely Paired Contacts
}

\begin{abstract}
K. Egashira and I. Sasada*
Interdisciplinary Graduate School of Engineering Sciences, Kyushu Univ., 6-1 Kasuga-koen, Kasuga-shi, Fukuoka 816-8580, Japan

"Faculty of Engineering Sciences, Kyushu Univ., 6-1 Kasuga-koen, Kasuga-shi, Fukuoka 816-8580, Japan

We designed a flexible pickup coil for torque sensors in which the offset is reduced as a result of the asymmetric structure, which was created in order to obtain an easy connection. The mutual inductance was calculated for all the possible coil patterns of an asymmetric configuration, and the coil pattern that exhibited the lowest mutual inductance was selected the best design for the pickup coil. In addition, the performance of a flexible pickup coil incorporating this design was evaluated by observing its offset voltage, response to the uniaxial magnetic anisotropy, and input-output characteristic. The results showed that the offset voltage was lowest in an asymmetric coil pair. The response to the uniaxial magnetic anisotropy showed an output pattern as the axis torque sensor. The input and output characteristics almost accorded with those of a conventional symmetric model coil pair.
\end{abstract}

Key words: torque sensor, flexible coil, figure-of-eight, offset, mutual inductance

\section{オフセット電圧を低減した結線容易なトルクセンサ用 フレキシブル検出コイルの設計および評価}

\author{
江頭広祐・笹田一郎* \\ 九州大学大学院総合理工学府, 福岡県春日市春日公園 6-1（率816-8580） \\ "九州大学大学院総合理工学研究院，福岡県春日市春日公園 6-1（T816-8580）
}

\section{1. はじめに}

近年，機械システムの発達に伴い，自動車などの回転駆動系の 制御のためにトルク検出の必要性が高まっている11).トルクが鋼軸 に印加されたとき，鋼軸表面に軸方向に対して 45 度方向に一軸 磁気異方性が誘起される。この一軸磁気異方性を測定することで トルクを非接触で検出できる ${ }^{2}$.

著者らはトルクを検出することを目的として，小型・薄型か 量産性を備えたフレキシブルプリント検出コイルを開発してきた 3). 図 1(a), (b)にフレキシブル検出コイルの概略図および実際の導 体のラインパターンを示す.このコイルは，時計回り，半時計回 り各 15 ターンからなる 180 度回転対称な平面 8 の字形のコイル 2 個からなり，その一方は，他方に対して直交するように配置され， それらの間に絶縁フィルムをはさみ，重ね合わせた構造である. 各コイルには，上下および左右のコイルの間にスペースが設けて あり, スルーホール加工を施して上下および左右のコイルを繋ぐ. このようなコイル対は，コイル間の正と負のインダクタンスの大 きさの平衡が保たれているため原理的に磁気結合がない4).コイル を鋼軸の軸方向に直交して非接触で設置した状態で卜ルクが印加 しない場合，一方を交流励磁し，他方の誘起電圧（オフセット電 圧）を測定しても出力は原理的にゼロである.

このコイル対は，図1(b)に示すように，励磁端子 $\mathrm{a} ， \mathrm{~b}$ および検 出端子 $\mathrm{c}, \mathrm{d}$ が互いに対角線上に位置する対称構造（刘称型コイル 対）であるため，コイルに配線する際に，リード線の取り回しが 不便であった．具体的には，リード線がコイル系をまたぐことに よってコンパクト性に欠ける, リード線に流れる電流による外乱 の影響を受け易いなどいった問題が生じる.この取り回しの問題 は，例えば，励磁端子 $\mathrm{b}$ および検出端子 $\mathrm{d}$ に導線を各 $1 / 2$ ターン
ずつ付加し, 端子 $\mathrm{a}$ と端子 $\mathrm{b}$, 端子 $\mathrm{c}$ と端子 $\mathrm{d}$ を近接した構造 (非 対称型コイル対）にすることで回避できる. しかし，8の字形コイ ル対としての対称性を犠牲にすることとなり，コイル間の正と負 の相互インダクタンスの平衡が崩れオフセット電圧が生じる.

本研究では, リード線の取り回しの不便さを解消し，かつ，才 フセット電圧を低減したフレキシブル検出コイルの構造を設計し た. また, 試作した検出コイルを, オフセット電圧, 一軸磁気異 方性への応答, さらにトルクセンサの入出力特性を測定し, 評価 した.

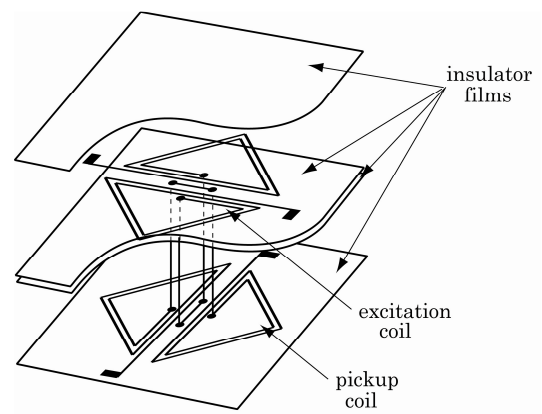

(a) Schematic diagram of a flexible coil

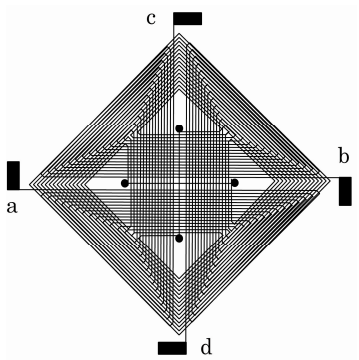

(b) Conductor patterns of a flexible coil. Pads a and b and pads $\mathrm{c}$ and $\mathrm{d}$ are located on different layers.

Fig. 1 Structure of a flexible coil. 


\section{2. フレキシブル検出コイルの設計}

オフセット電圧は 8 の字形コイル対の正および負の相互インダ クタンスの不平衡により生じる。まず，この相互インダクタンス の定量的な計算方法を述べる. さらに，非対称型コイル対の全て の構成パターンについて相互インダクタンスを計算し，その值が 最小となる構造を選択する.

\section{1 導線断面の影響}

Fig. 2 に今回検討寸るフレキシブル検出コイルの一辺の断面図 を示す.コイルの導線のラインアンドスペースは $100 \mu \mathrm{m}$, 厚みは $18 \mu \mathrm{m}$, 励磁，検出コイル間の距離は $50 \mu \mathrm{m}$, コイル外周の一辺 の長さは $15 \mathrm{~mm}$ である. まず, 相互インダクタンスの計算におい て, 励磁コイルと検出コイルの各導線断面に流れる電流分布の影 響を無視できるか否かについて考える.ここでは，この影響が最 大となる各コイルの導線が最も近接した平行線路間について考え る.

導線断面を考慮した相互インダクタンスは, 有限要素法を用い, 導線の長さを無限長とした二次元解析より, 空間内の全磁気エネ ルギーと導線に流れる電流から算出した，また，使用を想定して いる励磁周波数 $60 \mathrm{kHz}^{5}$ に において, 銅の表皮深さは約 $270 \mu \mathrm{m}$ と 導線の厚み $18 \mu \mathrm{m}$ および幅 $100 \mu \mathrm{m}$ に比べても充分に大きいので, 有限要素法は直流解析で行なった，励磁，検出コイルに流れる電 流 $I$ の向きが共に同じ場合の磁気エネルギ一を $W_{1}$, 互いに逆の場 合の磁気エネルギーを $W_{2}$ とすると, 相互インダクタンス $M$ は,

$$
M=\left(W_{1}-W_{2}\right) / 2 I^{2}
$$

から求められる. 導線断面を無視した導線間の相互インダクタン スは，電流が導線の断面中心にのみ流れると近似し，鎖交磁束よ り求めるよく知られた計算式 ${ }^{6)}$ より算出した. これら 2 つの方法 による解析は，励磁コイル側から代表として選んだ導線 1 と導線 1’15間において行なった.

Table 1 に導線 1 と導線 1'，8，15’ 間の相互インダクタンスを 示す．結果より，平行往復線路間の相互インダクタンスは，断面 積を考慮した場合と無視した場合の相互インダクタンスは約 $95 \%$ 以上で一致した．この一致は他の導線間においても確認できた. このことから, 今回検討寸る検出コイルの相互インダクタンスの 計算において，導線断面の影響は無視できるとしてよい.

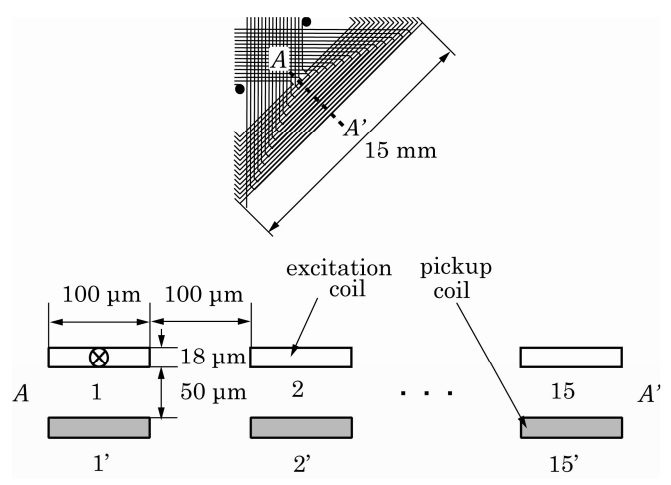

Fig. 2 Cross-section of a flexible coil.
Table 1 Mutual inductances calculated by an approximation formula and by the FEM.

\begin{tabular}{cccc}
\hline $\begin{array}{c}\text { Conductor number } \\
\text { of pickup side }\end{array}$ & $\# 1^{\prime}$ & $\# 8^{\prime}$ & $\# 155^{\prime}$ \\
\hline $\begin{array}{c}\text { Approximation } \\
\text { formula }(\mu \mathrm{H})\end{array}$ & 1.54 & 0.47 & 0.31 \\
\hline FEM $(\mu \mathrm{H})$ & 1.57 & 0.46 & 0.29 \\
\hline Error $(\%)$ & -1.59 & 3.03 & 5.06 \\
\hline
\end{tabular}

\subsection{8 の字形コイル対の相互インダクタンス}

Fig. 3 に 8 の字形コイル対の相互インダクタンス計算のための モデル図を示寸８ 8 字形コイル対は，励磁コイルを A と B，検 出コイルを $\mathrm{A}^{\prime}$ と $\mathrm{B}$ の 4 つの直角二等辺三角形に分けて考えること ができる.つまり，8の字形コイル対における励磁則コイルと検出 側コイル間の相互インダクタンス $M$ は,

$$
M=M_{A A^{\prime}}+M_{A B^{\prime}}+M_{B A^{\prime}}+M_{B B^{\prime}}
$$

と表される.

ここで $\mathrm{A}, \mathrm{A}^{\prime}$ 間の相互インダクタンス $M_{A A}$ の具体的な計算方法 について述べる. 2.1 より電流は導線の断面中心にのみ流れるとす る. A の導線 1 4, A’ の導線 1' 4’には, それぞれの導線が $N_{1} \sim N_{4}$, $N_{1} \sim N_{4}$ 本並ぶとすると, 相互インダクタンス $M_{A A}$ は, $\mathrm{A}$ の導線の 各線分と A'の導線の各線分のすべての組み合わせに対して存在す る相互インダクタンスの総和として求められる，また，直交する 線分間の相互インダクタンスは 0 であることに注意すれば, $M_{A A}$ は,

$$
\begin{aligned}
M_{A A^{\prime}} & =\sum_{i=1}^{N_{1}} \sum_{j=1}^{N_{2^{\prime}}} M_{12^{\prime}(i, j)}-\sum_{i=1}^{N_{1}} \sum_{j=1}^{N_{3^{\prime}}} M_{13^{\prime}(i, j)}-\sum_{i=1}^{N_{1}} \sum_{j=1}^{N_{4^{\prime}}} M_{14^{\prime}(i, j)} \\
& -\sum_{i=1}^{N_{2}} \sum_{j=1}^{N_{1^{\prime}}} M_{21^{\prime}(i, j)}+\sum_{i=1}^{N_{2}} \sum_{j=1}^{N_{3^{\prime}}} M_{23^{\prime}(i, j)}+\sum_{i=1}^{N_{2}} \sum_{j=1}^{N_{4^{\prime}}} M_{24^{\prime}(i, j)} \\
& +\sum_{i=1}^{N_{3}} \sum_{j=1}^{N_{1^{\prime}}} M_{31^{\prime}(i, j)}-\sum_{i=1}^{N_{3}} \sum_{j=1}^{N_{2^{\prime}}} M_{32^{\prime}(i, j)} \\
& +\sum_{i=1}^{N_{4}} \sum_{j=1}^{N_{1^{\prime}}} M_{41^{\prime}(i, j)}-\sum_{i=1}^{N_{4}} \sum_{j=1}^{N_{2^{\prime}}} M_{42^{\prime}(i, j)}
\end{aligned}
$$

と表される. ただし、電流の向きは各コイルにおいて時計回りと する. $M_{A B}, M_{B A} ; M_{B B^{\prime}}$ についても同様に表わすことができる.

ここで， $M_{12} ， M_{21}$ は平行配線間の相互インダクタンス，それ以 外は $2 つ の$ 線分の成す角度が 45 度の斜め配線間の相互インダクタ ンスである. 導線断面を無視した 2 つの線分間の相互インダクタ ンスは, Neumannの公式によって容易に計算できる7). 


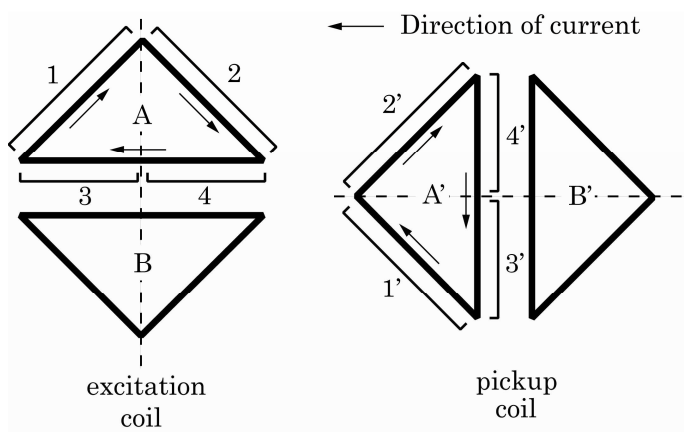

Fig. 3 Segmentation for the calculation.

\section{3 相互インダクタンスが最小となる検出コイル}

励磁コイルと検出コイルを各 $1 / 2$ ターンずつ付加し各端子が近 接させた非対称型コイル対は全ての場合を考慮すると 36 通りある これは一方のコイルで考えた場合，コイルを水平方向に反転，垂 直方向に反転，反転なしの 3 通りと，コイルを 180 度内面回転す るか否かの 2 通りあるため, $3 \times 2=6$ 通りある. 他方のコイルの場 合を合わせると $6 \times 6=36$ 通りになる. しかし，これらの場合には， コイル対を反転または 180 度内面回転させると構造が重複するも のが数多くありそれらを同一視すると 4 通りに絞ることができる.

Fig. 4 に従来の対称型コイル対および 4 通りの非対称型コイル 対のパターンのターン数を減らした簡略図を示寸. パターン A は 対称型コイル対の各コイルに導線を時計回りに $1 / 2$ ターンずつ付 加したコイル対, パターン $\mathrm{B}$ はパターン $\mathrm{A}$ の検出コイルを垂直方 向を軸に反転させたコイル対, パターン $\mathrm{C}$ はパターン $\mathrm{A}$ の検出コ イルを 180 度内面回転させたコイル対，パターン $\mathrm{D}$ はパターン $\mathrm{B}$ の検出コイルを 180 内面度回転させたコイル対である.

Table 2 に各コイルパターンにおける相互インダクタンスを示 す. 結果より, 非対称型の中で，パターン $\mathrm{A}, \mathrm{C}$ において相互イ ンダクタンスが最も小さいことが確認できた.
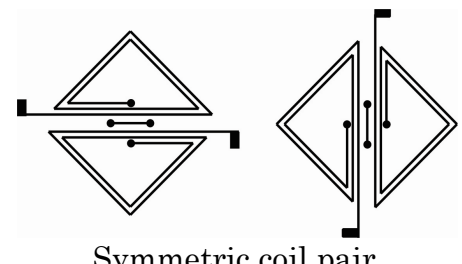

Symmetric coil pair.
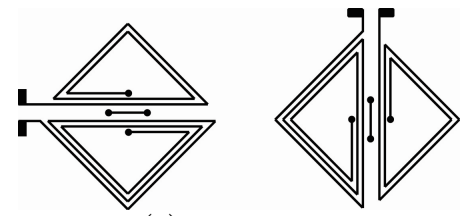

(a) Pattern A.
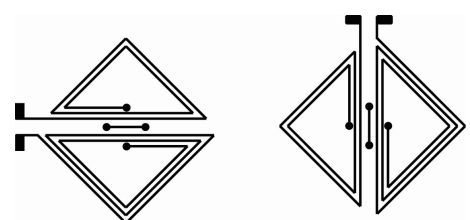

(b) Pattern B.
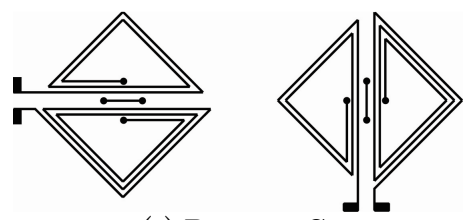

(c) Pattern C.
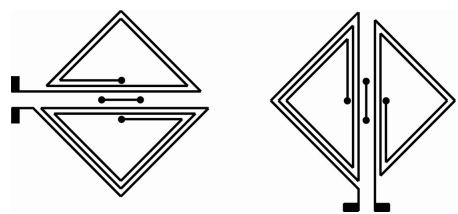

(d) Pattern D.

Fig. 4 Structural patterns of a flexible coil. The numbers of turns of the coil are reduced for simplicity.

Table 2 Mutual inductance of coil patterns.

\begin{tabular}{cccccc}
\hline $\begin{array}{c}\text { Coil } \\
\text { patterns }\end{array}$ & $\begin{array}{c}\text { Sym. } \\
\text { coil pair }\end{array}$ & A & B & C & D \\
\hline $\begin{array}{c}\text { Mutual } \\
\text { inductance } \\
(\mathrm{nH})\end{array}$ & 0 & 11.6 & 62.0 & -11.6 & 85.1 \\
\hline
\end{tabular}

\section{3. フレキシブル検出コイルの性能評価}

従来の対称型コイル対に加え, 非対称型コイル対のうち パターAおよびパターン $\mathrm{B}$ のフレキシブル検出コイルを試 作し，これらのオフセット電圧および一軸磁気異方性への 応答，さらにトルクセンサの入出力特性を比較し，軸トル クセンサとしての基本性能について評価した.

\section{1 オフセット電圧}

オフセット電圧は，空心のフレキシブル検出コイルにお いて, 励磁コイルに交流電流を流し, 検出コイルに誘起される電 圧をロックインアンプで同期整流し測定した．測定条件は，励 磁電流を $300 \mathrm{~mA}$, 励磁周波数を $60 \mathrm{kHz}$ とした. 結果を Table 3 を示す. 結果より, Table 2 で相互インダクタンス がより小さくなったパターン $\mathrm{A}$ のオフセット電圧の方が低 いことがわかる．また，相互インダクタンスの計算方法の 有効性は，各パターンにおける Table 2 で示した相互イン ダクタンス および Table 3 で示したオフセット電圧の比 （相互インダクタンス/オフセット電圧）より確認できる. これは，オフセット電圧は 8 の字形コイル対の相互インダ クタンスと比例関係であるためである。この結果，比は， パターン A で約 0.19 , パターン $\mathrm{B}$ で約 0.17 と近い值を示 し, 相互インダクタンスの計算方法の有効性を確認できた.

Table 3 Offset voltage of coil alone.

\begin{tabular}{cc}
\hline Coil patterns & $\begin{array}{c}\text { Offset voltage } \\
(\mathrm{mV})\end{array}$ \\
\hline Sym. coil pair & 0.6 \\
\hline Pattern A & 4.2 \\
\hline Pattern B & 25.2 \\
\hline (Excitation current $=300 \mathrm{mV})$
\end{tabular}

(Excitation current $=300 \mathrm{mV})$ 


\section{2 一軸旃嵫異方性への応答}

一軸磁気異方性への応答は，励磁コイルに交流電流を流 し, 一軸磁気異方性を持つ磁性体を近接させてコイル系に 対して 360 度回転させたときに検出コイルに誘起される電 圧をロックインアンプで同期整流し測定した。一軸磁気異 方性は, Fig. 5 に示すように, 幅 $1 \mathrm{~mm}$ にスリットした長 さ $60 \mathrm{~mm}$ のアモルファスリボン(METGLAS2714A)を多数 平面のプラスチックシート上に一方向かつ密に並べること によって作り出すことができる，これは，細長い磁性体は 長軸方向に磁化容易軸を持つためである. 本論文では, こ のシートを一軸磁気異方性シートと呼ぶこととする.この シートの大きさは幅が $60 \mathrm{~mm}$, 長さが $60 \mathrm{~mm}$ である. 軸 トルクセンサ用検出コイルとして応用する場合, フレキシ ブル検出コイルの応答は, 一軸磁気異方性印加方向が 45 , $135 ， 225 ， 315$ 度で最大出力点を同振幅で示し, 符号は交 番しなければならない2)。ただし, Fig. 1(b)の端子 c, d 方 向が 0 度方向である.

測定条件は, 励磁電流を $50 \mathrm{~mA}$, 励磁周波数を $60 \mathrm{kHz}$, 同期位相を出力が最大となる 69.8 度とした.また, 検出コ イルと一軸磁気異方性シート間の空隙は, $0.3 \mathrm{~mm}$, フレキ シブル検出コイルの背面には, バックヨークとしてコイル 面と同形状のアモルファス薄帯（METGLAS 2714A）を一 枚貼付した.

Fig. 6 および Fig. 7(a)，（b)に一軸磁気異方性印加方向に 対する出力電圧を示す. 結果より, 印加方向が 45,135 , 225,315 度のときの出力は, 対称型コイル対および非対称 型コイル対パターン A においてほぼ一致し, 共に軸トルク センサ用検出コイルとしての応答を確認できた. しかし, 非対称型コイル対パターン $\mathrm{B}$ は， $45 ， 225$ 度方向の出力が 135, 315 度方向の出力に比べ大きく, 軸トルクセンサ用検 出コイルとしての応答を示さない. これはオフセット電圧 が約 $30 \mathrm{mV}$ もあり, この電圧が誘起電圧に 45,225 度方 向で同位相, 135,315 度方向で逆位相となって重畳された ためである。

\section{3 入出力特性}

Fig. 8 に 3.2 で軸トルクセンサとしての一軸磁気異方性 への応答が確認できた対称型コイル対および非対称型コイ ル対パターン A のトルクセンサの入出力特性を示す. 測定 条件は, 励磁電流を $300 \mathrm{~mA}$, 励磁周波数を $60 \mathrm{kHz}$, 同期 位相を出力が最大となるー137 度とした. また, 検出コイ ルと軸間の空隙が $0.3 \mathrm{~mm}$, 検出コイルにはバックョーク としてアモルファス薄帯（METGLAS 2714A）を一枚貼付 した。また, 軸には優れた磁気特性と機械強度を備えた SUS403 のスリーブと SUS304 の軸による冷やしバメ軸 8) を用いた。結果は, 対称型コイル対と非対称型コイル対パ ターンAの入出力特性が約 $95 \%$ 以上で一致した.つまり, パターン A の空心状態で生じていたオフセット電圧は, フ レキシブル検出コイルにバックヨークを貼付し軸に取り付 けることで無視できる.これはオフセット電圧が出力振幅
に対して十分に小さくなるためである. また, 出力特性の 非線形性は，感度が高いとダイナミックレンジが小さくな るのが一般的であることから，本トルクセンサの場合， SUS403 のスリーブ厚が $500 \mu \mathrm{m}$ と薄く高感度であり, 大 きな印加トルクによって出力が飽和したことによって現れ た.

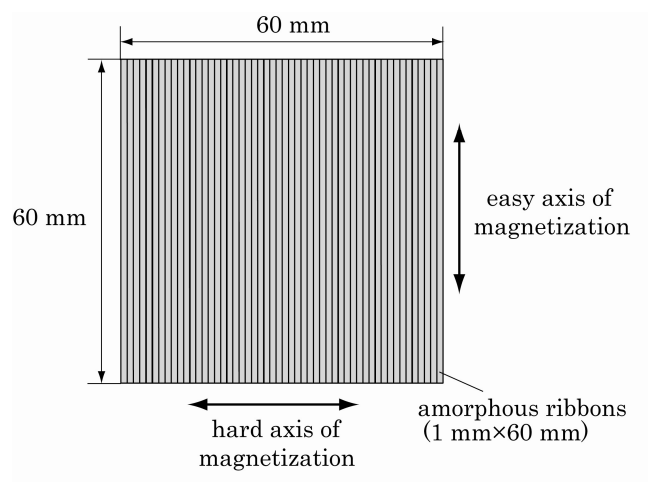

Fig. 5 Sheet with uniaxial magnetic anisotropy.

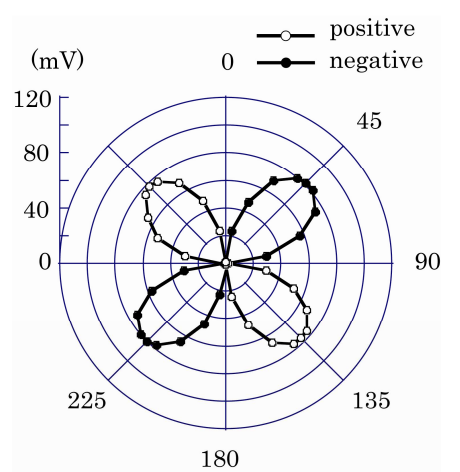

Fig. 6 Output of a symmetric coil pair.

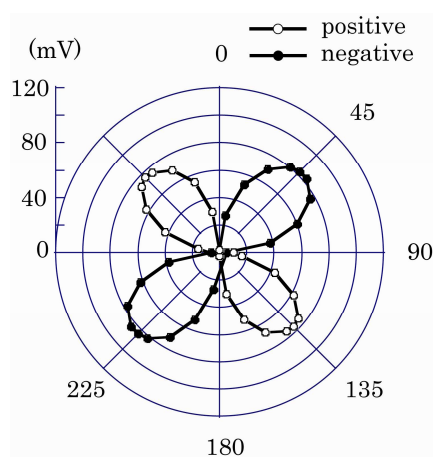

(a) Pattern A.

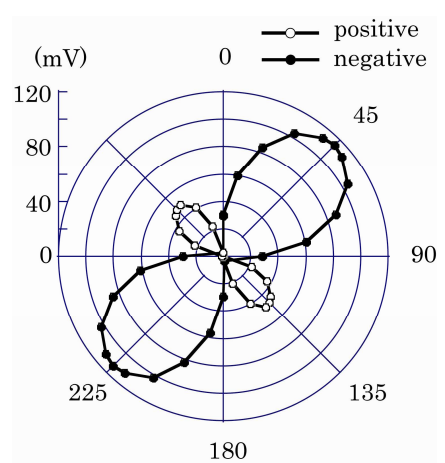

(b) Pattern B.

Fig. 7 Output of an asymmetric coil pair. 


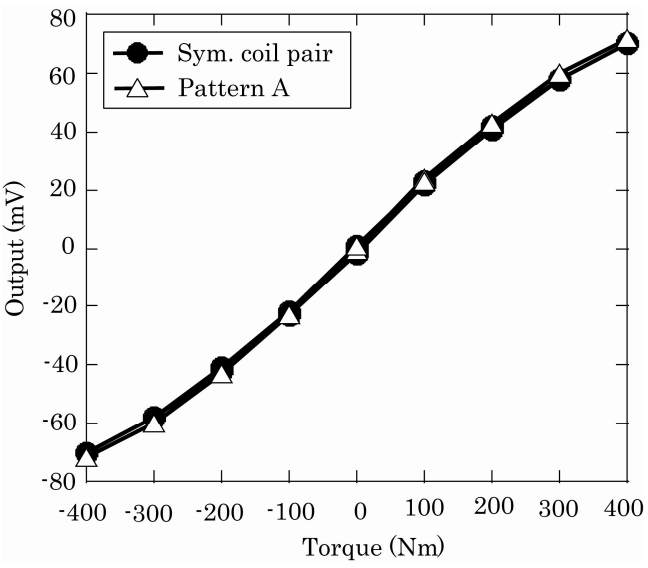

Fig. 8 Input-output characteristics.

\section{4. まとめ}

本論文では，対称構造を持つフレキシブルコイルへのリード線 の結線を容易にするために, 非効称な構造一変形し, 可能なコイ ルパターンの中でオフセット電圧が最小となるコイル設計を実現 した. 設計は, 励滋コイルと検出コイルー各 $1 / 2$ ターンずつ導線パ ターンを付加し各端子を近接させた非対称型コイル対全てについ て相互インダクタンスを計算し，その值が最小となる構造を選択 することで行なった．計算の結果，相互インダクタンスは，リー ド線の取り回しの向きや位置によって大きく変化し, 対称型コイ ル対の各コイルに導線を $1 / 2$ ターンずつ付加したコイル対(本文パ ターンA）およびこのコイル対の検出コイルを 180 度内面回転さ
せたコイル対（本文パターン C) で最小となった，また，本設計 によって試作したフレキシブル検出コイルの性能をオフセット電 圧, 一軸磁気異方性への応答, さらにトルクセンサの入出力特性 を測定した. その結果, オフセット電圧は, 非対称型コイル対の 中で最小となった。一軸磁気異方性一の応答は, 異方性印加方向 が $45,135,225,315$ 度で最大出力点を同振幅で示し, 符号は交 番する軸トルクセンサとしての出力パターンを示した. 入出力特 性は，従来の対称型コイル対とほぼ一致し，空心状態で生じてい たオフセット電圧の影響は, フレキシブル検出コイルにバックヨ ークを貼付し軸に取り付けることでほぼ無視できる程度まで小さ くできた.

以上のことより，結線が容易でオフセット電圧を低減したトル クセンサ用フレキシブル検出コイルを開発することができた.

\section{References}

1) S. Larsson and I. Andersson: Control Enginnering Practice, 16, 505 (2008)

2) O. Dahle: ASEA Jounal, 33, 3, (1960).

3) I. Sasada, Y. Etoh, and K. Kato: IEEE Trans. Magn., 42, 3309 (2006).

4) I. Sasada and M. Akinaga: J. Appl. Phys., 91, 7792 (2002).

5) I. Sasada and F. Koga: J. Appl. Phys., 75, 5916 (1994).

6) K. Goto, and S. Yamasaki: Shokai Denjikigakuenshuu (in Japanese), p. 278 (Kyoritsu Shuppan, Tokyo, 1970).

7) F. W. Grover: Inductance Calculations, p. 55 (Dover Publications, New York, 1946).

8) Y. Eto, T. Kato, Y. Habata, and I. Sasada: Tech. on Magnetics, IEE Japan, MAG-05-35 (2005) (in Japanese)

2008年3月17日受理，2008年7月14日採録 